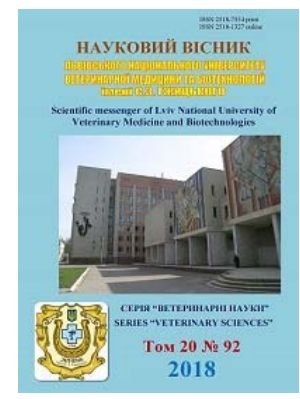

\author{
Науковий вісник Дьвівського національного університету \\ ветеринарної медицини та біотехнологій імені С.З. Гжицького
}

\author{
Scientific Messenger of Lviv National University \\ of Veterinary Medicine and Biotechnologies
}

UDC 619:618.14:636:612.1

\title{
Clinical and haematological indices of the cows for acute catarrhal-purulent endometritis
}

\author{
L.V. Koreyba
}

Dnipro State Agrarian and Economic University, Dnipro, Ukraine

Article info

Received 23.10.2018

Received in revised form 22.11 .2018

Accepted 23.11.2018

Dnipro State Agrarian and Economic University, Serhiya Yefremova Str., 25, Dnipro, 49000, Ukraine.

Tel.: +38-056-68-33-77

E-mail:lyudkorflk@gmail.com
Koreyba, L.V. (2018). Clinical and haematological indices of the cows for acute catarrhal-purulent endometritis. Scientific Messenger of Lviv National University of Veterinary Medicine and Biotechnologies, 20(92), 121-124. doi: 10.32718/nvlvet9225

Postpartum inflammatory processes in the genital organs are enough common reason of prolonged symptomatic infertility, which is from 10 to $72 \%$ of the total dairy herd of cows and are often registered in the form acute endometritis. The goal of the work was to study non-specific indicators resistance in healthy and illness with catarrhal purulent endometritis of cows. The haematological tests research were carried out during the winter-spring period on cows of four groups, which were formed on the basis of analogues and on the basis of clinical and gynaecological investigations. Presented data regarding special feature of clinical signs of postnatal endometritis in cows. In cows during the puerperal period recorded acute serous of endometritis purulent-catarrhal. The acute catarrhal purulent endometritis causes in cows significant changes in the morphological composition of blood and all investigated units of natural resistance. In illness cows with compared to healthy ones pregnant cows have had an undoubted increase in haemoglobin content (by 15.4\%), the number of eosinophils and neutrophils which core has rod shape; an increase in the number of leukocytes (by 8.3\%) and a decrease in lymphocytes, bactericidal (10.42\%) and lysozyme activity of plasma $(0.96 \%)$ was not reliable. The low index of phagocytic activity for acute postpartum endometritis suggests the inhibition of phagocytosis in the body of illness cows. The acute catarrhal purulent endometritis causes in cows significant changes in the morphological composition of blood and all investigated units natural resistance. The low index of phagocytic activity for such state as acute postpartum endometritis suggests the inhibition of phagocytosis in the body of illness cows. Further work will be focused on the using of indices of non-specific resistance of cows for prediction and correction of inflammatory processes in the uterus.

Key words: cows, puerperal period, purulent-catarrhal endometritis puerperal, morphological composition of blood, nonspecific resistance, haemoglobin, eosinophils, neutrophils, leukocytes, lymphocytes, bactericidal activity, lysozyme activity.

\section{Клініко-гематологічні показники корів за гострого катарально-гнійного ендометриту}

\author{
Л.В. Корейба
}

Дніпровський державний аграрно-економічний університет, м. Дніпро, Україна

\footnotetext{
Мета досліджень полягала у вивченні показників неспецифічної резистентності у здорових і хворих на катарально-гнійний ендометрит корів. Клінічні ознаки гострого катарально-гнійного ендометриту відмічали на 7-14-ту добу післяродового періоду. Зміна загального стану тварин проявлялася зниженням апетиту, загальним пригніченням та зменшенням продуктивності. 3 родових шляхів хворих тварин спостерігались виділення гнійно-слизового ексудату жовто-бурого кольору з неприємним гнильним запахом та з частинками тканин посліду. У хворих корів порівняно зі здоровими породіллями спостерігається вірогідне зростання вмісту гемоглобіну (на 15,4\%), кількості еозинофілів та паличкоядерних нейтрофілів; невірогідне зростання кількості лейкоцитів (на 8,3\%) та зниження лімфочитів, бактерицидної (на 10,42\%) та лізоџимної активності плазми крові (на 0,96\%). Низький показник фагоцитарної активності за гострого післяродового ендометриту свідчить про пригнічення фагоцитозу в організмі хворих корів. Подальша робота буде зосереджена на використанні показників неспецифічної резистентності корів для прогнозування та корекиії запальних процесів у матиі в період пуерперію.
} 
Ключові слова: корови, пуерперій, післяродовий катарально-гнійний ендометрит, морфологічний склад крові, неспеиифічна резистентність, гемоглобін, еозинофіли, паличкоядерні нейтрофіли, лейкоцити, лімфоцити, бактерицидна активність, лізоцимна активність.

\section{Вступ}

Репродуктивна здатність корів і їх молочна продуктивність суттєво залежать від перебігу родів і післяродового періоду, від строків завершення інволюційних процесів у статевих органах корови.

Серед причин зниження відтворної здатності корів значне місце займають хвороби післяродового періоду. Патологія післяродового періоду у корів має значне поширення і складає 33,8\% (Zvierieva et al., 2000; Koreyba et al., 2015; Koreyba, 2017).

Огріхи в годівлі та догляді за тільними тваринами призводять до недостатньої підготовки родових шляхів до виведення плоду, дистанції родів материнського та плодового походження, затримки посліду, що є головною причиною запальних процесів у матці в період пуерперію. Післяродові запальні процеси в статевих органах $\epsilon$ досить поширеною причиною тривалої симптоматичної неплідності, яка складає від 10 до 72\% усього молочного стада корів і досить часто реєструються у формі гострого ендометриту (Zvierieva et al., 2000; Zvierieva et al., 2001; Koreyba et al., 2015; Koreyba, 2017).

Враховуючи складну етіологію та патогенез катарально-гнійного ендометриту у корів, розлади загального обміну речовин, нейроендокринної регуляції, системи імунного захисту організму, важливим є подальше вивчення даної патології.

Тому мета наших досліджень полягала у вивченні показників неспецифічної резистентності у здорових і хворих на катарально-гнійний ендометрит корів.

\section{Матеріал та методи досліджень}

Нами були проведені гематологічні дослідження впродовж зимово-весняного періоду на коровах чотирьох груп, які були сформовані за принципом аналогів, і на основі клінічного огляду та гінекологічного обстеження. До першої та другої групи віднесені корови другої-третьої вагітності за місяць до отелення. За рівнем післяродової захворюваності дородові показники цих груп обраховувались окремо у тварин з фізіологічним та патологічним перебігом післяродового періоду.

Тварини $з$ фізіологічним перебігом були віднесені до першої групи (здорові, контроль), з паталогічним - до другої групи (схильні до ендометриту - схильність визначали за післяродовою захворюваністю).

Дві останні групи формувались 3 корів другоїтретьої лактації на 7-14 добу після родів, з яких третя група - клінічно здорові (контроль), четверта - тварини, хворі на гострий катарально-гнійний ендометрит.

Нами були проведене гематологічне дослідження крові за загально прийнятими методиками (Vlizlo et al., 2012).

\section{Результати та їх обговорення}

При аналізі етіології післяродових захворювань загалом і ендометриту зокрема було з'ясовано, що у дослідних корів вони з'явилися внаслідок патологічних родів при травмуванні слизової оболонки матки, на фоні затримання посліду та субінволюції матки. Лише у 5,6\% породілль післяродовий ендометрит виникав після нормального отелення. Всього ця патологія у господарстві уражала до 48\% породілль щорічно (40\% в літній та $52 \%$ в зимово-весняний період). При детальному вивченні причин ендометриту було ще з'ясовано, що у 38,5\% корів запальний процес виникав через затримання посліду.

Клінічні ознаки гострого катарально-гнійного ендометриту відмічали на 7-14-ту добу післяродового періоду. Зміна загального стану тварин проявлялася зниженням апетиту, загальним пригніченням та зменшенням продуктивності. 3 родових шляхів хворих тварин спостерігались виділення гнійно-слизового ексудату жовто-бурого кольору з неприємним гнильним запахом та з частинками тканин посліду. Хворі корови горбилися, тужилися і займали вимушену позу, характерну для сечовипускання, що супроводжувалося порційним виділенням ексудату, який в особливо великій кількості виявляли на підстилці, де лежали хворі тварини.

Ректальним дослідженням відзначали збільшення об'єму матки, яка була опущена в черевну порожнину, a iii розміри були такими, як при двомісячній вагітності; стінки іiі були тістуватої консистенції, при пальпації проявлялася слабка больова реакція; шийка матки була у напіввідкритому стані. На вульві, корені хвоста та сідничних горбах виявляли засохлі бурі кірочки.

\section{Таблиця 1}

Гематологічні показники крові корів до і після родів $(\mathrm{M} \pm \mathrm{m})$

\begin{tabular}{lcccrr}
\hline \multicolumn{1}{c}{ Групи тварин } & Еритроцити, & \multirow{2}{*}{ Гемоглобін, г/л } & $\begin{array}{c}\text { Кольоровий } \\
\text { показник }\end{array}$ & $\begin{array}{c}\text { ШОЕ, } \\
\text { мм/год }\end{array}$ & $\begin{array}{c}\text { Лейкоцити, } \\
\text { Г/л }\end{array}$ \\
\hline & \multicolumn{3}{c}{ До родів } \\
\hline Здорові $(\mathrm{n}=18)$ & $7,20 \pm 0,36$ & $134,79 \pm 4,84$ & $0,97 \pm 0,05$ & $1,30 \pm 0,16$ & $9,87 \pm 0,63$ \\
Схильні до ендометриту $(\mathrm{n}=15)$ & $7,47 \pm 0,31$ & $136,88 \pm 4,12$ & $0,94 \pm 0,05$ & $1,22 \pm 0,08$ & $10,06 \pm 0,62$ \\
\hline & \multicolumn{3}{c}{ Після родів } \\
\hline Здорові $(\mathrm{n}=13)$ & $7,39 \pm 0,50$ & $120,13 \pm 4,15$ & $0,85 \pm 0,07$ & $1,17 \pm 0,14$ & $9,37 \pm 0,57$ \\
Хворі на ендометрит $(\mathrm{n}=13)$ & $7,03 \pm 0,38$ & $138,60 \pm 5,25 * *$ & $1,02 \pm 0,07$ & $0,98 \pm 0,07$ & $10,15 \pm 0,64$ \\
\hline Примітка $*$ * $<<0,05, * *-\mathrm{P}<0,01$ порівняно зі здоровими тваринами
\end{tabular}

Примітка: * $-\mathrm{P}<0,05,{ }^{* *}-\mathrm{P}<0,01$ порівняно зі здоровими тваринами 
В дородовий період у здорових та схильних до ендометриту корів кількість еритроцитів, лейкоцитів, вміст гемоглобіну, кольоровий показник, ШОЕ вірогідно не відрізнялись (табл. 1). Після родів у здорових тварин знизився вміст гемоглобіну, проявилась тенденція до зниження інших показників, за винятком еритроцитів. У хворих тварин, порівняно зі здоровими породіллями, на фоні низької кількості еритроцитів (на 4,87\%), був вірогідно вищим вміст гемоглобіну на $15,38 \%(\mathrm{P}<0,01)$ та спостерігалась тенденція до зростання кількість лейкоцитів (на 8,32\%).

Гострий запальний процес в організмі тварин чітко позначився на структурі лейкоформули їхньої крові (рис. 1).

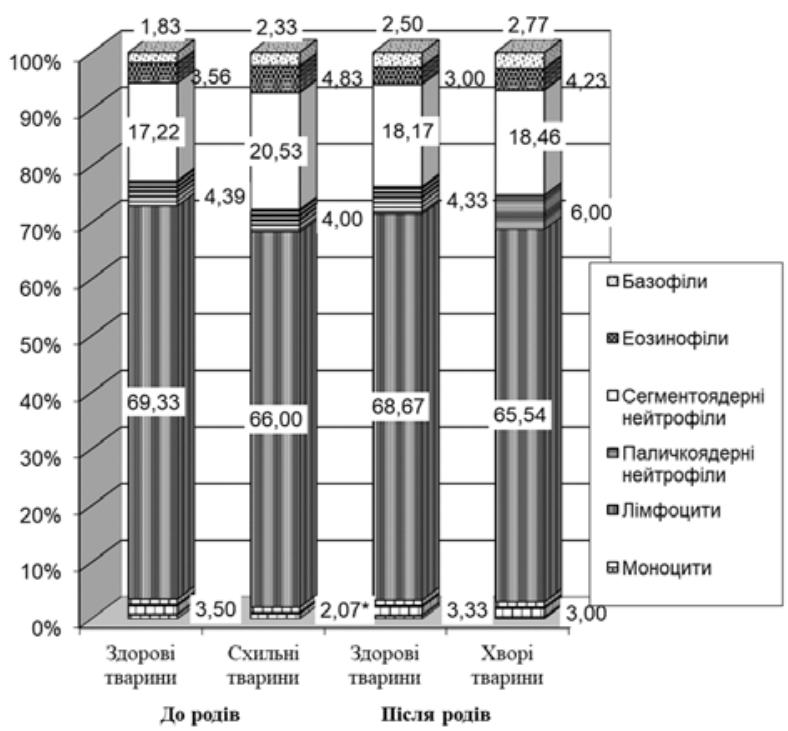

Рис. 1. Лейкоформула крові корів до і після родів Примітка: * $-\mathrm{P}<0,05,{ }^{* *}-\mathrm{P}<0,01$ порівняно зі здоровими тваринами

Таблиця 2

Неспецифічна реактивність організму корів до і після родів $(\mathrm{M} \pm \mathrm{m})$

\begin{tabular}{lccc}
\hline \multicolumn{1}{c}{ Групи тварин } & Фагоцитарна активність, \% Бактерицидна активність, \% & Лізоцимна активність, \% \\
\hline \multicolumn{3}{c}{ До родів } \\
\hline Здорові $(\mathrm{n}=18)$ & $65,53 \pm 2,02$ & $45,24 \pm 2,62$ & $8,78 \pm 0,87$ \\
Схильні до ендометриту $(\mathrm{n}=15)$ & $64,33 \pm 1,54$ & $42,69 \pm 2,17$ & $7,63 \pm 0,73$ \\
\hline \multicolumn{3}{c}{ Після родів } \\
\hline 3дорові $(\mathrm{n}=13)$ & $64,83 \pm 1,99$ & $53,04 \pm 2,81$ & $9,25 \pm 0,73$ \\
Хворі на ендометрит $(\mathrm{n}=13)$ & $64,54 \pm 2,38$ & $42,62 \pm 2,14 * *$ & $8,29 \pm 0,85$ \\
\hline
\end{tabular}

Примітка: ${ }^{*}-\mathrm{P}<0,05,{ }^{*}-\mathrm{P}<0,01$ порівняно зі здоровими тваринами

\section{Висновки}

1. В умовах Пр-АТ “Агро-Союз” Синельниківського району Дніпропетровської області післяродовий ендометрит у корів найчастіше перебігає в катарально-гнійній формі запалення i характеризується загальним пригніченням, зменшенням продуктивності та виділенням зі статевих органів патологічного ексудату кашкоподібної консистенції жовто-бурого кольору 3 неприємним гнильним запахом й домішками гною та частинок тканин посліду.
У схильних до ендометриту корів кількість моноцитів була достовірно нижчою і досягала 2,07\% $(\mathrm{P}<0,05)$ в порівняно зі здоровими.

Відмічено тенденцію збільшення у хворих на ендометрит корів кількості еозинофілів, паличкоядерних нейтрофілів і зниження лімфоцитів. Щодо відсоткового співвідношення базофілів та моноцитів, то помітних змін в їхній кількості на початкових стадіях розвитку запального процесу не встановлено.

Отримані нами експериментальні дані свідчать, що при розвитку післяродового септичного запалення відбуваються зміни неспецифічної резистентності. Передусім ми спостерігали тенденцію до збільшення загальної кількості лейкоцитів, яке супроводжувалось істотними змінами їхнього структурного співвідношення (збільшення відсотка нейтрофілів), що є свідченням гострого перебігу запального процесу.

Крім того, у дослідних тварин ми досліджували бактерицидну, фагоцитарну i лізоцимну активності (табл. 2).

При вивченні фагоцитарної активності виявлено, що у клінічно здорових тварин вона вища, ніж у хворих, як до родів, так і після них (відповідно 65,53 $2,02 \%$ проти $64,33 \pm 1,54 \%$ і $64,83 \pm 1,99 \%$ проти $64,54 \pm 2,38 \%)$. Низький показник фагоцитарної активності свідчить про пригнічений фагоцитоз в організмі тварин, хворих на гострий післяродовий ендометрит.

Зниження до і після родів бактерицидної (відповідно на 2,55\% і 10,42\% (P < 0,01) та лізоцимної активності плазми крові (відповідно на $1,15 \%$ і $0,96 \%$ ) у корів, хворих на ендометрит, свідчить про послаблення факторів неспецифічної природної резистентності організму та зниження стимуляції фагоцитозу.
2. Гострий катарально-гнійний ендометрит обумовлює у корів суттєві зміни морфологічного складу крові та всіх досліджених ланок природної резистентності. У хворих корів порівняно зі здоровими породіллями спостерігалися на фоні низької кількості еритроцитів (на 4,87\%) вірогідно вищий вміст гемоглобіну на $15,38 \%$ (Р < 0,01), тенденція до зростання кількості лейкоцитів (на 8,32\%) і зниження лімфоцитів, фагоцитарної, лізоцимної активності плазми крові, бактерицидної (на 10,42\% (Р < 0,01), що свідчить про послаблення факторів неспецифічної природної резистентності організму та зниження стимуляції фагоцитозу. У схильних до ендометриту корів кіль- 
кість моноцитів була достовірно нижчою і досягала $2,07 \%(\mathrm{P}<0,05)$ порівняно зі здоровими.

Перспективи подальших досліджень. Подальша робота буде зосереджена на використанні показників неспецифічної резистентності корів для прогнозування та корекції запальних процесів у матці в період пуерперію.

\section{References}

Zvierieva, H.V., Khomyn, S.P., Teranovets, V.I. ta in. (2000). Akusherska i hinekolohichna dyspanseryzatsiia u systemi profilaktyky neplidnosti ta mastytiv u koriv. Nauk. visnyk nats. ahrar. un-tu, 22, 21-23 (in Ukrainian).

Koreyba, L.V., Makieieva, N.S., \& Zolotonosha, K. (2015). Poshyrennia akusherskoi patolohii u koriv holshtynskoi porody $\mathrm{V}$ umovakh pryvatnoho aktsionernoho tovarystva "Ahro-Soiuz" Synelnykivskoho raionu Dnipropetrovskoi oblasti.
Problemy zooinzhenerii ta veterynarnoi medytsyny: Zbirnyk naukovykh prats Kharkivskoi derzhavnoi zooveterynarnoi akademii, 30(2), 78-82. http://nbuv.gov.ua/UJRN/pzvm_2015_30\%282\%29 23 (in Ukrainian).

Koreyba, L.V. (2017). Osoblyvosti klinichnoho proiavu pisliarodovykh endometrytiv $\mathrm{u}$ koriv $\mathrm{v}$ umovakh pryvatnoho pidpryiemstva "Ahro-Soiuz" Synelnykivskoho raionu Dnipropetrovskoi oblasti. Perspektivnye innovacii v nauke, obrazovanii, proizvodstve i transporte: Sb. tezisov. Ivanovo: Nauchnyj mir, 9-14. https://www.sworld.com.ua/konfer49/7.pdf (in Ukrainian).

Vlizlo, V.V., Fedoruk, R.S., Ratych, I.B. ta in. (2012). Laboratorni metody doslidzhen $\mathrm{u}$ biolohii, tvarynnytstvi ta veterynarnii medytsyni dovidnyk. Lviv: SPOLOM (in Ukrainian).

Zvierieva, H.V., Yablonskyi, V.A., \& Kosenko, M.V. (2001). Rekomendatsii Z profilaktyky neplidnosti khudoby. K.: Nauk. svit, 18 (in Ukrainian). 